\title{
Religion and Esotericism among Students: A CrossCultural Comparative Study
}

Franz Höllinger

Timothy B. Smith

Brigham Young University, tbs@byu.edu

Follow this and additional works at: https://scholarsarchive.byu.edu/facpub

Part of the Counseling Psychology Commons

\section{Original Publication Citation}

Höllinger, F., \& Smith, T. B. (2002). Religion and esotericism among students: A cross-cultural comparative study. Journal of Contemporary Religion, 17, 229-249.

\section{BYU ScholarsArchive Citation}

Höllinger, Franz and Smith, Timothy B., "Religion and Esotericism among Students: A CrossCultural Comparative Study" (2017). Faculty Publications. 2006.

https://scholarsarchive.byu.edu/facpub/2006 
Höllinger, F., \& Smith, T. B. (2002). Religion and esotericism among students: A cross-cultural comparative study. Journal of Contemporary Religion, 17, 229-249.

\author{
Religion and Esotericism among students \\ A cross-cultural comparative study \\ Franz Höllinger and Timothy B. Smith
}

\title{
1. Introduction
}

Cross-national comparative studies have shown significant differences among contemporary societies in regard to religious beliefs and religious behaviour. In the majority of European countries, Christian beliefs have lost their credibility and religious practice has decreased continuously during the past century (Jagodzinski/Dobbelaere 1993; Höllinger 1996; Mol 1972; Zulehner/Denz, 1993). This trend seems to confirm the widely accepted sociological thesis that secularisation and disenchantment with the world are inevitable concomitants of the process of modernization. Belief and practice in other parts of the world, however, indicate that religion and modernity are by no means incompatible. In the Islamic world, religion has maintained its central position in public and private life. Also in the United States and in Latin America the Christian religion is still very popular, and newly emerging evangelical churches have attracted a considerable part of the population during the past few decades (Martin 1990; Corten 1996; Marty/Appleby 1992).

Another important dimension of the religious change in contemporary Western societies is the New Age movement: the rediscovery of magic and renewal of esoteric and spiritual beliefs and techniques. Beginning as a small counterculture movement in the sixties, New Age activities and esoteric literature have become increasingly popular, in particular among the younger generation and among higher-educated strata. The common beliefs and goals of this movement, its characteristic activities and practices, and the social and cultural developments which led to its development have been analysed and explained in a large number of studies (Berger/Berger/Dreitzel 1973; Bellah 1976; Knoblauch 1989; Stenger, 1993; Bochinger 1994; Hanegraaff 1996; Heelas 1996). However, only a few good empirical studies have investigated the dissemination of occult and esoteric beliefs and practices, and almost no cross-national studies have been conducted on this topic. 
To fill this gap in the research, we conducted an empirical study in five European and five American countries. We chose university students as subjects for our investigation from both practical and topic-appropriate considerations. Because the reception of New Age literature and esoteric techniques is higher in the younger and middle-age cohorts and in the highereducated middle classes than among elder and less educated persons, students seem to be a population well suited for comparing the dissemination of New Age beliefs and practices in different societies. Using student samples has allowed us to investigate an additional dimension: the relationship of academic disciplines and religious worldviews. This analysis has enabled us to explore new findings, complementing and contesting previous research results in this area. Moreover, this analysis will give insights into the psychic and social determinants of the current affinity towards New Age esotericism.

This article deals with two principal research-objectives: (a) analysis of the association of academic disciplines and religious world views and (b) description and explanation of crossnational differences in religiousness and affinity towards esotericism.

Academic disciplines and religious world views. The incompatibility between modern scientific thinking and religious world views (in regard to the creation of the world, religious miracles etc.) has been considered one of the main reasons why religious beliefs and rituals have lost their credibility in modern societies (Durkheim 1965; Lübbe 1986). Accordingly, research on this topic has assumed that persons trained in natural-scientific thinking, particularly those working in academic professions, should be less religious than others. In a survey conducted as early as 1916, James Leuba confirmed this assumption: he found that among 1000 randomly selected American scientists, 60\% did not believe in God, a significantly higher percentage than in the overall population. Moreover, religious beliefs were lower among scientists with higher academic status (in terms of awards and citations) than among scientists with lower status (see Larson/Withamv 1997 p. 435). However, a replication of Leuba's study carried out in the last decade did not confirm Leuba's prediction that religious disbelief among scientists would increase in the future (idem, 436). The percentage of (American) scientists who believe in God remained more or less the same from the beginning to the end of the $20^{\text {th }}$ century.

Comparing the religious beliefs and religious experience of scientists from different academic disciplines, several studies have found that natural scientists and students of the natural sciences are more religious than social scientists and students of social-scientific disciplines (see Beit-Hallahmi, 1998, p. 281). Lehmann and Shriver (1968) explained this 
difference with the "scholarly distance" hypothesis: Scientists will apply critical thinking in particular to the area they are dealing with, while they will be less critical in regard to fields of knowledge which are more distant from their own domain. Thus natural scientists will apply critical thinking primarily to phenomena concerning nature, while social scientists will be more critical in regard to society, culture, and religion. Therefore, social scientists will be more likely to question religious beliefs, rituals and institutions than will natural scientists (Beit-Hallahmi, 1998, p. 282). In the pilot study for this project, carried out at the University of Graz, Austria, we found no consistent differences among areas of study in regard to Christian religiosity. With the exception of theology students, who have high scores on all indicators of religiousness, the majority of the students from the other academic disciplines reported to have distanced themselves from Christian beliefs and practice. However, we found strong and consistent differences in regard to esoteric/occult beliefs and practices: Students of the exact sciences (engineering, natural sciences), of economy, and of law tended to reject esotericism significantly more than did students of music, sociology and education; students of medicine and of languages were in an intermediate position (Höllinger 1999, p. 59).

Our results concerning Christian religiosity among students from different areas of science are not congruent with the scholarly-distance hypothesis cited above. Nevertheless, this hypothesis may help to explain why natural scientists reject esoteric beliefs and paranormal phenomena more than do social scientists: They do so, because they are more aware that these phenomena contradict the established laws of the natural sciences. However, the differences among the exact and the social sciences in regard to esoteric beliefs might also be explained by sociological or psychological theories.

Applying Max Weber's thesis of the disenchantment of the world (Weber 1988, 594) to our subject of study, we can formulate the following hypothesis: The more a science is concerned with planning, calculating and controlling the processes in nature and in society, the more its members will desist from believing that natural and social phenomena are influenced by supernatural forces, spirits or magical powers. Accordingly, we should expect that students of natural, technical, and economic sciences are more distant from religion and esotericism. Students of subjects that are concerned with the emotional, intuitive and irrational aspects of human life, which employ not only positivist methods but also hermeneutic and phenomenological methods of cognition, such as the arts and the human and social sciences, will be more receptive to religious and esoteric phenomena. 
Similar conclusions can be derived from the psychological concept of “androgyny.” This concept asserts that every human being, regardless of his/her biological gender, has so-called "male" and "female" personality traits; these traits can be more or less balanced, or one of the poles, male or female, predominates. "Male” personalities can be characterised as more analytical, rational, active, competitive and self-confident, while "female" personalities are more sensitive, intuitive, receptive and insecure (Keller 1978; Bierhoff-Alvermann 1989). According to this thesis, we should expect that "male" personalities would chose technical, natural and economic sciences, which require a high degree of mathematical and analytical thinking, and sciences such as economy and law, which provide good chances for advancing into top positions in the fields of economy, politics and public administration. At the same time, "male" personalities would be less sensitive to and more sceptical about religion and esotericism. Correspondingly, “female” personalities would more likely choose studies such as arts and music, languages and social sciences, which use not only mathematical and statistical, but also hermeneutic and phenomenological methods of cognition and thus give more opportunity for intuition and sensitivity. Hence, “female” personalities would be more receptive to religious and esoteric phenomena.

Another rationale for the differences among academic disciplines in their affinity towards esotericism was provided by the pilot study cited above. In this study we found that students of the social sciences and of music are more likely to participate in political protest activities (such as demonstrations and strikes) and to vote green-ecologist and left-opposition parties than are students of the exact sciences, of law and of medicine. The tendency of social scientists to adopt more radical political positions in comparison to scholars of the natural and technical sciences, who tend to be more conservative, has been affirmed elsewhere in the scientific literature (see Beit-Hallahmi 1998, 183). However, the pilot study clearly supports the thesis of the overlap between the New Age movement and other countercultural political protest movements (Berger/Berger/Dreitzel 1973; Bellah 1976; Knoblauch 1989, 264; Barker 1993, 246; Mörth 1989, 297-302; Hanegraaff 1996, 514): Participation in New Age activities is positively correlated with participation in political protest activities and sympathy for green-ecologist politics. Thus we formulated the following hypothesis: In contemporary Western societies, students with counter-cultural world views are likely to have an affinity towards the New Age movement; at the same time these students are more likely than others to choose disciplines which give more space for engaging in such world views, as is the case for the social sciences and the arts. 
According to this hypothesis one should expect that students of the social sciences and of the arts are more critical towards traditional religion and the Christian churches because of their predominantly conservative ideological positions. How then might one explain the findings that there are no differences between students of the social sciences and students of the natural sciences in Austria in this regard, while various studies have found such differences in the United States? One explanation may be that in the present youth generation Christian religion is not as controversial a social issue as it was 20 or 30 years ago, when the American studies were carried out. Perhaps also in those countries where the Christian churches have maintained their central position in society, such as the USA or the Latin American countries, religion is a more controversial issue among intellectuals and students than in the highly secularised European countries.

Religion and Esotericism in cross-national comparison: Since our study is based on student samples, it is necessary first to raise the question of whether students are a particular segment of the population that is more similar to students in other countries than to the rest of their own society in regard to religiousness, or whether the level of religiousness of students is similar to that of the rest of the population of the same age cohort. Cross-national comparative studies, such as the International Social Survey Programme (ISSP) and the World Value Survey (WVS), support the view of age and culture similarity. Comparing indicators of religiosity such as attending religious service, praying, expressing belief in God and in heaven and hell etc., one finds only a few countries where students and more highly educated persons are less religious than lower educated persons from the same age cohort. In most countries, there are no significant differences, or religiousness is even higher among higher educated persons (Höllinger 1996, 104). Generally the level of religiousness of students and academics corresponds to the level of religiousness of the population of the rest of the country.

Accordingly, we expected that in regard to religious practice and Christian beliefs our study would show cross-national differences similar to those found in previous studies: Students from the Germanic culture area in Middle and Northwest Europe should have a lower level of religiousness than students from Southern European countries. Religiousness should be even higher in the USA (see Zulehner/Denz 1993, 18-47; Höllinger 1996, 76-94). Latin American Countries have not yet participated in cross-national studies on religion, and we did not have access to any representative population data on religion for these countries. According to the literature on religion in Latin America (Parker 1998, 196; Pierucci/Prandi 1996), we 
should expect that people in Latin America, thus students from these countries, would have a high level of Christian belief and religious practice.

Esoteric beliefs have been investigated with a cross-national perspective in the study "World Views in Modern Society.” This study, also based on student samples, found a significantly higher percentage of students who believe in occult phenomena, in astrology and in spiritual beings in Poland and in Mexico than in Western European Countries (Scandinavian Countries, Holland and Germany). In the former countries students also reported more frequently that they had had mystic experiences than in the latter countries (Bergbom/Björkqvist/Holm 1996, 36-42). Since the process of socio-economic modernisation has started later and the level of socio-economic development is significantly lower in Mexico and Poland than in Western Europe, it is plausible to assume that the belief in spiritual beings and occult phenomena decreases in the course of modernisation, as Max Weber has argued in his thesis of the disenchantment of the world. Following this argumentation, we hypothesise that the belief in occult and esoteric phenomena will be higher in the economically less developed countries (Latin American countries and Portugal), than in the highly developed countries (Western European countries and USA).

The dissemination of New Age activities, such as spiritual exercises (like Yoga and Zenmeditation), alternative medicine and therapies, esoteric methods for achieving a higher consciousness of oneself (like astrology and Tarot-cards) etc., has not yet been examined systematically in cross-national perspective. According to estimates reported by Mörth (1989, 307) and Heelas (1996, 108-113), around 4\% of the population of Western European countries and of the USA are regularly involved in New Age activities. Besides the relatively small core group of New Age activists, a larger circle of persons are attracted to the New Age world-view and sometimes participate in New Age activities.

Some New Age techniques, like faith-healing, geomantics, fortune-telling, and astrology, belong to the traditional repertoire of healing and counselling practices of pre-industrial societies; in the course of modernisation, these techniques have been replaced to a large extent by pharmaceutics medicine and modern psychology (Waßner 1984; Müller 1989, 19-25). Accordingly, such practices should be more popular in the less developed countries of Latin America than in Northwest Europe and in the USA. However, these practices have been "rediscovered" by the New Age Movement, which has originated in the urban centres of the highly developed late-capitalist societies. Thus these practices may also gain in popularity in more highly developed countries. A large number of esoteric and spiritual practices have been 
derived from non-western, in particular from Asian cultures and have been introduced into Western culture only in recent times. Such practices - oriental spiritual techniques, Tantra, IGing, Tarot-cards, Reiki etc. - have been disseminated through esoteric literature and New Age workshops. Since New Age is a reaction to the life-conditions in highly industrialised societies, we assume that the supply and the demand for New Age literature and New Age workshops is larger in Western Europe and the United States than in South America and Portugal. Therefore, students in the former countries should have more access to and more experience with these esoteric practices.

\section{Methodology}

The research instrument, a standardised questionnaire, was inspired by the "World Views Study," a cross-national comparative study of the relationship of religious and political world views of students to their personalities (Holm/Björkqvist 1993), the "International Social Survey Programme” (ISSP), and the "World Value Study” (WVS) (see Zulehner/Denz 1993). The questionnaire for the pilot study was developed and fielded during a course in Methods of Research at the University of Graz in 1998. The final version of the questionnaire was worked out with the cooperation of social scientists from Austria, Brazil and Argentina. ${ }^{1}$

This questionnaire was fielded in 1999 among 3,569 students from 16 universities in 10 American and European countries: Argentina, Brazil, Colombia, Uruguay, USA, Austria, Germany, Great Britain, Italy and Portugal. ${ }^{2}$ In order to guarantee that the samples were comparable, the following sampling procedure was applied at all participating universities: At each university, courses from four to eight academic disciplines were selected in such a way that at least two disciplines from the exact sciences (technical, economic and natural sciences), and two disciplines from the human sciences (health sciences, social sciences, languages and arts) were included. The questionnaires were distributed and filled out in the classroom by the students of the selected courses. Participation was voluntary, but in the majority of the selected

\footnotetext{
${ }^{1}$ Franz Höllinger from the University of Graz, Austria; Deis E. Siqueira and Lourdes Bandeira from the Universidade de Brasília, Brazil; Maria del Rosario Contepomi from Universidad Nacional de Missiones, Argentina.

${ }^{2}$ The following universities participated in the study (sample size in parenthesis): Argentina: Universidad Nacional de Missiones (271); Austria: Karl-Franzens-Universität Graz (255); Brazil: Universidade de Brasília (332); Universidade Federal de Goiás (200); Universidade Federal de Paraiba (296), Universidade Federal do Rio Grande do Sul (225), Universidade Estadual de Londrina (256); Columbia: Universidad Pontificia Bolivariana, Medellin (200); Germany: Johann-Wolfgang-Goethe Universität, Frankfurt/M (283); Europa Universität Viadrina, Frankfurt/Oder (298); Great Britain: University of London (211); Italy: Universitá degli Studi, Trento (229); Portugal: Universidade de Lisboa (156); Uruguay: Universidad Católica del Uruguay, Montevideo (172); USA: University of South Dakota (226); University of Southern Colorado (49).
} 
groups almost everybody participated. Thus even if the resulting samples are not representative for the population of the respective universities, all kinds of students, not only those who feel closer to religion and/or to esotericism, were included in the sample.

\section{Empirical results}

\subsection{Description of the scales}

The central dimensions of our study were measured with the following scales:

a) Religious practice: frequency of praying, attending religious services and reading the bible (Cronbach's alpha=.80).

b) Religious beliefs: belief in God, Jesus, Virgin Mary, Holy Spirit, devil, angels, saints, heaven, hell, afterlife (alpha=.92). The item-battery for religious beliefs included also the Oriental concepts of karma and reincarnation. Between these two items and the Christian beliefs, we found weak positive correlations, indicating that belief in karma and reincarnation is not incompatible with Christian beliefs. However, the reliability coefficient for the scale is higher when the Asian beliefs are excluded from the scale.

c) Occult beliefs: belief in nature spirits (fairies etc.), spirits in old houses, contact with dead, psychic-healers, telepathy, clairvoyance, astrology, healing energies of stones (alpha=.85). In addition to these items, the item battery included belief in extra-terrestrials ("somewhere in the universe there exist intelligent beings, apart from mankind”). This item, which was agreed to by around 60 percent of the overall sample, is only weakly correlated with the rest of the items and diminishes the reliability of the scale. Since the majority of the items in this list refer to so-called occult or paranormal phenomena, we will designate this scale as "occult beliefs.”

d) New Age activities: practicing Asian spiritual techniques like Yoga or Tai Chi, meditation, acupuncture, alternative medicine (e.g. homeopathy, Bach-flowers), psychotherapy, massage-techniques like Shiatsu, psychic healing, attention to the phases of the moon, Tarot cards or I-Ging, dream-interpretation, fortune telling, horoscope or astrology (alpha=.72). Some of these methods, such as psychotherapy or acupuncture, cannot be considered as exclusively New Age activities; however, the reliability-test shows that students with an affinity to esoteric methods such as astrology or Tarot-cards are more likely than others to practice psychotherapy, too. The factor analysis for the overall sample divides this item list 
into three sub-dimensions: (1) esoteric methods for predicting events and for analysing one's personality: fortune-telling, Tarot-cards, astrology, also “dream-interpretation”; (2) bodyoriented spiritual techniques: Asian techniques like Yoga, Zen or Tai Chi, meditation and massage techniques like Shiatsu; (3) alternative healing-methods: alternative medicine, faith-healing, acupuncture; also "observation of moon-phases” and "psychotherapy.” The three factors, in particular the second and the third factor, are positively correlated. This finding confirms a characteristic aspect of New Age activism, which has been highlighted in many studies about New Age: the tendency of New Age activists not to concentrate on one technique, but to experiment with several techniques at the same time or one after another.

In the following, we will use the term "New Age affinity" or "affinity towards esotericism" when we refer to the complex of occult beliefs and New Age activities, keeping in mind that not all persons believing in occult phenomena or practising activities from the list described above have an affinity towards the New Age movement.

\subsection{Cross-cultural patterns of religiousness and affinity towards esotericism}

Based on theoretical considerations and on statistical pre-examinations, the 10 participating countries were divided into 4 culture areas: (1) Latin America: Argentina, Brazil, Columbia and Uruguay; (2) USA; (3) Northwest Europe: Austria, Germany, Great Britain. (4) South Europe: Italy and Portugal. The international "Europa Universität Viadrina" in Frankfurt/Oder, Eastern Germany, has a high number of Eastern European students, particularly Polish. Thus the sample from this university includes 60 Polish students. These students are clearly different from the German and other Northwest European students in regard to both religiosity and esotericism. Since they do not fit into the group of the South European students, and since there are no other representatives from Eastern Europe, we will omit the Polish students from the following comparison and will deal with them separately at the end of this section. 
Table 1: Religiosity of Students, by Culture-Area

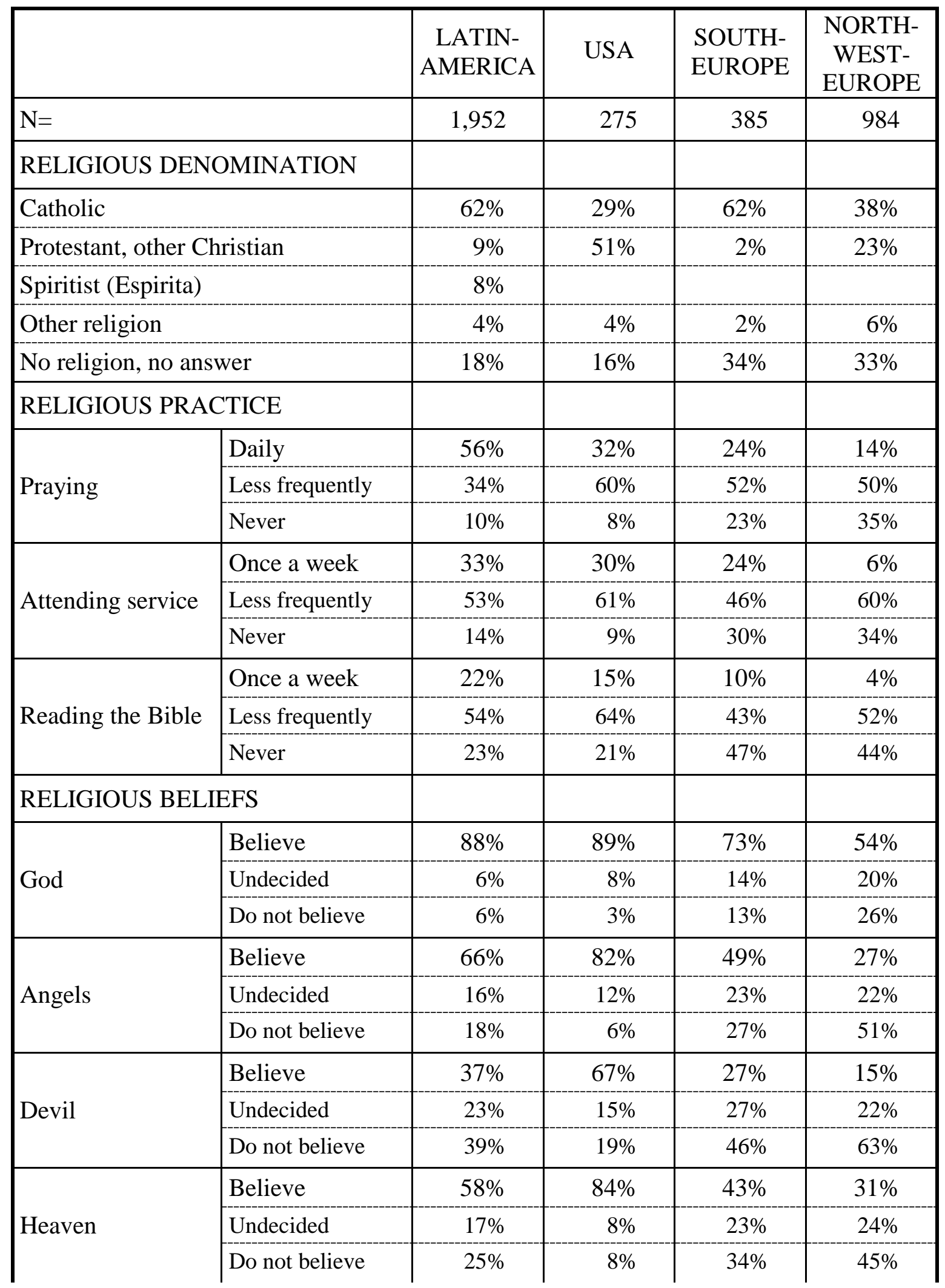




\begin{tabular}{|l|l|c|c|c|c|}
\hline \multirow{3}{*}{ Hell } & Believe & $39 \%$ & $72 \%$ & $28 \%$ & $16 \%$ \\
\hline & Undecided & $23 \%$ & $12 \%$ & $28 \%$ & $24 \%$ \\
\cline { 2 - 6 } & Do not believe & $38 \%$ & $16 \%$ & $44 \%$ & $60 \%$ \\
\hline
\end{tabular}

Table 1 presents the results for religious denomination, religions practice, and religious belief of students by culture area. The denominational structure of the students in the four culture areas can be summarized as follows: Latin-American students are predominantly Catholic; however, this area includes considerable minorities of Protestants and of Spiritists, i.e. followers of the doctrine of the French Spiritist Allan Kardec. ${ }^{3}$ The two South European countries are almost exclusively catholic. In the US-American sample, 50\% are members of Protestant denominations, one-third are Catholic. In the Western European countries, the majority of students who consider themselves as church members are Catholic or are members of the dominant Protestant church, the Anglican Church in England and the Lutheran Church in Germany and Austria. The category "other religion” is composed of members of Asian religions and of Afro-Brazilian cults (in Brazil and Argentina), as well as Jews, Moslems (the religion of students from Islamic countries in European universities), and a few students who declared esoteric doctrines (e.g. theosophy, witchcraft) as their religion. In the European countries, one-third of the students declared that they have no religion or did not answer the question; in Latin America and the United States the percentage is only half as high.

As far as it was possible to compare the results of our study with representative population data from the ISSP and WVS, the denominational structure and the level of religiousness in our study did not differ much from that of the total population (of the younger age cohorts) of the respective countries. ${ }^{4}$ Students in Latin American Countries and in the USA are much more religious than Northwest European students; South European students are in an intermediate position. One third of the North and South American students, compared with only 6\% of the Northwest European students, attend a religious service every week. The presence of religion in everyday life in Latin America is indicated by the extraordinary high 56\% of respondents who pray daily, and over $20 \%$ who read the Bible at least once a week. The differences in regard to religious beliefs are similarly striking. For example, around $80 \%$ of the US American, $60 \%$ of the Latin-American, $40 \%$ to $50 \%$ of the South European and $30 \%$ of the Northwest European

\footnotetext{
${ }^{3}$ The denominational structure and the changes of religious life in Latin-America in the last decades have been examined by: Ferreira de Camargo 1973, Martin 1990, Pierucci/Prandi 1996.

${ }^{4}$ For the Latin American countries we did not dispose of representative population data. Studies carried out in particular regions of Brazil (ISER) indicate that in the overall population the number of Protestants is higher, and the number of Spiritists somewhat lower than in our student samples.
} 
students believe in angels and in heaven. Two thirds of US American students also believe in the devil and in hell, whereas in all other countries these representations of the negative side of the traditional Christian cosmos have much less plausibility.

To explain these cross-national differences would require a complex analysis, taking account of many factors. In this article we can only give some rough suggestions. For a long time, the most influential approach for explaining secularisation has been the modernisation theory, which holds that socio-cultural and religious change is a concomitant of socio-economic development (see Kaufmann 1989). In our opinion, however, the different patterns of religiousness in Christian societies can be explained only partly by this factor. The acceptance or rejection of Christian beliefs and religious rituals in a given society depends partially on the role which the Christian churches have played in the history of that society, and on the social functions of the churches in present times. In most European societies, for centuries there has been a powerful state church, whose leaders were members of the political elite; these churches did not support the interests of the people, but those of the elite. As a reaction, many social and revolutionary movements (e.g. the French Revolution; Enlightenment; the communist and socialist movements) had anticlerical and anti-religious tendencies (see Martin 1980). Unlike in Europe, in the United States religion was separated from the political sphere from the beginning; a large number of Christian denominations and free choice of religion has been available (Münch 1986, 257-80). Thus the role of religion in society was never perceived as problematical, as it was in Europe. Latin American countries are in an intermediate position between Europe and the USA: Catholicism was imposed on the indigenous population, and for a long time was the only officially permitted religion. However, in the vast and scarcely populated territories of Latin America it was much more difficult than in Europe to provide a sufficient number of clergy and to control the religious behaviour of the population (Moreira Alves 1979, 17-40; Rios 1994, 21-41, Ferreira de Camargo 1973, 74-77). Under the surface of Christian religion the people were able to maintain their authentic native creeds and rituals. The vitality of mystic and ecstatic spirituality in Latin America manifests itself in the success of the Pentecostal churches and of the Catholic Charismatic movement in the last decades. The hierarchy of the Catholic Church has had an ambivalent social role in the course of history. As in Europe, the higher clergy tended to identify with the ideological position of Rome and with the interests of the political and economic elite. However, the lower clergy defended the interests and rights of the poorer population, many times against the hierarchy of the Church and against the authorities of the state. There is an additional factor for the popularity of religion in Latin America and in the USA: Social inequality in these countries is stronger, and social 
welfare politics are less developed than in Europe. As a consequence to the high rates of geographic mobility, in combination with extreme forms of social inequality, a large part of the lower classes in North and South American cities live in anomic life-conditions; thus theft, robbery and physical violence are much more widespread than in Europe. Therefore, the churches in America much more than in Europe have the important function of providing financial, social and emotional support to their members (Niebuhr 1929; Höllinger 1996).

Table 2: Occult Beliefs of Students, by Culture-Area

\begin{tabular}{|c|c|c|c|c|c|}
\hline & & $\begin{array}{c}\text { LATIN- } \\
\text { AMERICA }\end{array}$ & USA & $\begin{array}{l}\text { SOUTH- } \\
\text { EUROPE }\end{array}$ & $\begin{array}{c}\text { NORTH- } \\
\text { WEST- } \\
\text { EUROPE }\end{array}$ \\
\hline \multicolumn{2}{|l|}{$\mathrm{N}=$} & 1.952 & 275 & 385 & 984 \\
\hline \multirow{3}{*}{ Fairies } & Believe & $24 \%$ & $24 \%$ & $18 \%$ & $14 \%$ \\
\hline & Undecided & $31 \%$ & $40 \%$ & $31 \%$ & $23 \%$ \\
\hline & Do not believe & $45 \%$ & $36 \%$ & $51 \%$ & $62 \%$ \\
\hline \multirow{3}{*}{ Contact with dead } & Believe & $30 \%$ & $32 \%$ & $17 \%$ & $12 \%$ \\
\hline & Undecided & $30 \%$ & $35 \%$ & $39 \%$ & $24 \%$ \\
\hline & Do not believe & $40 \%$ & $34 \%$ & $44 \%$ & $64 \%$ \\
\hline \multirow{3}{*}{ Clairvoyance } & Believe & $28 \%$ & $26 \%$ & $17 \%$ & $22 \%$ \\
\hline & Undecided & $40 \%$ & $53 \%$ & $39 \%$ & $25 \%$ \\
\hline & Do not believe & $33 \%$ & $21 \%$ & $45 \%$ & $52 \%$ \\
\hline \multirow{3}{*}{ Psychic Healers } & Believe & $44 \%$ & $30 \%$ & $28 \%$ & $23 \%$ \\
\hline & Undecided & $30 \%$ & $40 \%$ & $37 \%$ & $29 \%$ \\
\hline & Do not believe & $26 \%$ & $30 \%$ & $36 \%$ & $48 \%$ \\
\hline \multirow{3}{*}{ Telepathy } & Believe & $54 \%$ & $52 \%$ & $41 \%$ & $47 \%$ \\
\hline & Undecided & $24 \%$ & $30 \%$ & $34 \%$ & $27 \%$ \\
\hline & Do not believe & $21 \%$ & $19 \%$ & $25 \%$ & $25 \%$ \\
\hline \multirow{3}{*}{ Astrology } & Believe & $31 \%$ & $25 \%$ & $24 \%$ & $20 \%$ \\
\hline & Undecided & $28 \%$ & $36 \%$ & $32 \%$ & $23 \%$ \\
\hline & Do not believe & $41 \%$ & $39 \%$ & $44 \%$ & $57 \%$ \\
\hline
\end{tabular}

As well as religious belief, belief in occult phenomena such as nature-spirits, contact with dead, clairvoyance, psychic healers, telepathy and astrology is more widespread in Latin America than in Europe (see Table 2). To our surprise, belief in occult phenomena is also relatively high among the US American students. This result contradicts our hypothesis that the belief in occult phenomena should be higher in the less developed than in the more highly 
developed countries. Besides these differences, the results for belief in occult phenomena show similar tendencies across culture areas. Between $15 \%$ and $30 \%$ of the students in the single countries believe in spirits, in contact with dead, and in astrology. A considerable number between $25 \%$ and $50 \%$ per country - are undecided whether or not such phenomena exist. Telepathy is considered as trustworthy by around half of the students in all countries; only $20 \%$ to $25 \%$ contest the existence of this phenomenon.

For the item list of New Age activities three answer categories were offered in the questionnaire: "practicing regularly," "have practiced several times," and "have practiced once or a few times." The percentage of students who practice such activities regularly is rather small: $1 \%$ to $6 \%$ for the single activities. In Table 3, the three categories have been summed up to one category. The cross-cultural comparison gives a complex pattern. Our hypothesis that students from more economically developed countries should have more experiences with activities which have been introduced into Western culture from other cultures is confirmed for several items: The percentage of students who are practicing or have practiced Asian spiritual techniques, acupuncture, meditation, and massage-techniques is significantly higher in Western Europe than in Latin America and South Europe; it is higher also among students from politically, economically and culturally more important cities (Brasilia, Montevideo, Medellin) than among students from more provincial cities (Posadas in Argentina, João Pessoa and Londrina in Brazil). The data also confirm our assumption that the traditional esoteric methods of fortune telling and faith healing should be more popular in Latin America than in Europe. Contrary to our expectation, the data show almost no cross-cultural differences in regard to psychotherapy and esoteric methods such as Tarot-cards, I-Ging etc. Students from the metropolitan cities in Latin America have practiced such activities even more often than students from Western Europe. In comparison to students from other countries, the results for the US American students show some surprising peculiarities: While around $50 \%$ of the students in Europe and Latin America have used alternative medicine (homeopathy, Bachflowers etc.), in the USA only $25 \%$ have used these methods. On the other hand, many more students in the USA than in the other countries have consulted a fortuneteller or an astrologer. This result is congruent with the relatively high rates of belief in occult phenomena among US American students. A possible explanation for this result is that because of the precarious social conditions under which they live many US Americans turn not only to religion, but also to esoteric methods in search of emotional support and emotional security. 
Table 3: New Age Activities of Students, by Culture-Area

\begin{tabular}{|c|c|c|c|c|}
\hline & $\begin{array}{c}\text { LATIN- } \\
\text { AMERICA }\end{array}$ & USA & $\begin{array}{l}\text { SOUTH- } \\
\text { EUROPE }\end{array}$ & $\begin{array}{c}\text { NORTH- } \\
\text { WEST- } \\
\text { EUROPE }\end{array}$ \\
\hline $\mathrm{N}=$ & 1,952 & 275 & 385 & 984 \\
\hline \multicolumn{5}{|l|}{ Respondent has practiced $^{1} \ldots$} \\
\hline Oriental spiritual practice & $15 \%$ & $25 \%$ & $16 \%$ & $35 \%$ \\
\hline Meditation & $32 \%$ & $44 \%$ & $25 \%$ & $52 \%$ \\
\hline Acupuncture & $8 \%$ & $8 \%$ & $3 \%$ & $14 \%$ \\
\hline Alternative medicine & $47 \%$ & $25 \%$ & $42 \%$ & $52 \%$ \\
\hline Psychotherapy & $18 \%$ & $16 \%$ & $12 \%$ & $15 \%$ \\
\hline Massage-techniques & $20 \%$ & $23 \%$ & $17 \%$ & $40 \%$ \\
\hline Psychic healing & $14 \%$ & $11 \%$ & $5 \%$ & $5 \%$ \\
\hline Observing the phases of the moon & $35 \%$ & $17 \%$ & $28 \%$ & $22 \%$ \\
\hline Tarot, I-Change, Runes & $18 \%$ & $17 \%$ & $15 \%$ & $18 \%$ \\
\hline Dream-interpretation & $35 \%$ & $51 \%$ & $39 \%$ & $49 \%$ \\
\hline Fortune-telling & $17 \%$ & $28 \%$ & $10 \%$ & $9 \%$ \\
\hline Interpreting the Horoscope & $16 \%$ & $41 \%$ & $25 \%$ & $23 \%$ \\
\hline \multicolumn{5}{|c|}{$\begin{array}{l}\text { Number of activities which respondent } \\
\text { has practised at least once or a few times }\end{array}$} \\
\hline None & $21 \%$ & $23 \%$ & $24 \%$ & $13 \%$ \\
\hline $1-2$ & $33 \%$ & $27 \%$ & $37 \%$ & $29 \%$ \\
\hline $3-4$ & $24 \%$ & $23 \%$ & $23 \%$ & $29 \%$ \\
\hline 5 or more & $21 \%$ & $28 \%$ & $16 \%$ & $30 \%$ \\
\hline \multicolumn{5}{|c|}{$\begin{array}{l}\text { Number of activities which respondent } \\
\text { is practising regularly }\end{array}$} \\
\hline None & $80 \%$ & $87 \%$ & $83 \%$ & $79 \%$ \\
\hline 1 & $12 \%$ & $8 \%$ & $10 \%$ & $12 \%$ \\
\hline 2 & $4 \%$ & $2 \%$ & $4 \%$ & $4 \%$ \\
\hline 3 or more & $4 \%$ & $3 \%$ & $3 \%$ & $4 \%$ \\
\hline
\end{tabular}

Footnote 1: "processing regularly" + "have practised several times" + "have practised once or a few times".

In the second part of Table 3 the results for New Age activities have been summarized in order to facilitate the cross-cultural comparison. First, we calculated how many of the 12 activities each student has practiced at least once or a few times. The figures show that a relatively small portion of the students - 12\% in Northwest Europe, around 20\% in America, 24\% in South Europe - have had no personal experience at all with New Age activities. The majority have tried one or another New Age activity. A considerable number of students $-30 \%$ in Europe and in the USA, 21\% in Latin America, and 16\% in South Europe have practiced 5 or more of the 12 activities. The percentage of students who practice a particular method 
regularly is much smaller of course. Around 20\% of the students in Europe and Latin America, and somewhat fewer in South Europe and the USA, reported that they practice at least one method regularly; $4 \%$ specified 3 or more methods which they practice regularly. This percentage corresponds more or less to the number which has been given in various studies as an estimate for the core group of New Age activists in Western societies.

Representative population data from the International Social Survey Programme (ISSP1998) on "Religion" show that in most countries included in this study occult and magic beliefs are more widespread among less educated than among more highly educated persons. Thus our student sample probably underestimates the occurrence of occult beliefs in the respective countries. In Austria, a list of New Age activities similar to that of our student survey was attached to the ISSP-1998-questionnaire. According to the results of this survey, people between 25 and 40 years have the highest rate of participation in New Age activities. Within the same age cohort, we found clear differences between levels of education: more highly educated persons are more interested in spiritual techniques (Yoga, meditation etc.) and in esoteric techniques which come from other culture areas (Tarot, I-Ging), while less educated persons are more likely to consult fortune tellers or faith healers and to pay attention to the phases of the moon when carrying out certain activities.

We will conclude this section with a graphic presentation of the location of the participating countries in regard to religious beliefs and practice and to occult beliefs and New Age activities. Chart $1 \mathrm{a}$ and Chart $1 \mathrm{~b}$ are based on the standardised mean values of the 11 countries, including the Polish students as an additional case. As Chart 1a indicates, religious beliefs and religious practice are highly correlated on the aggregate level of countries $(r=.85$, with a high positive correlation of $r=.57$ between these two dimensions on the level of individual cases). Chart 1a also shows that the countries belonging to a particular culture area are in most cases located close to each other: The level of religiousness is lowest among Northwest European students and highest among South American and US American students; South European and Polish students are in an intermediate position. The scatterplot for occult beliefs vs. New Age activities (Chart 1b) does not give such a clear picture. There is practically no correlation between these two dimensions on the aggregate level of countries $(r=-.03$, though on the individual level, these two dimensions are positively correlated, $\mathrm{r}=.42$ ). Also the cultural and geographic macro-areas cannot be distinguished that clearly from the spatial location of the countries. Nevertheless, one can see, that the Latin American countries are located closer to the left upper corner, while Northwest European countries are located more at the right bottom side of the chart: i.e. Latin American students have relatively high scores on occult beliefs and low 
scores for New Age activities, while Northwest European students tend to reject occult phenomena, but are more likely to practise New Age activities. Polish students are in an intermediate position in regard to belief in occult phenomena. According to ISSP-1998, occult beliefs (belief in fortune-tellers, faith-healers, and astrology) are clearly more widespread in Poland and in other Eastern European countries than in Western European countries. This result corresponds to our hypothesis that in economically less developed societies traditional occult beliefs should be more popular. However, contrary to our hypothesis, the Polish students in our study also have had more experiences with New Age activities than the students from any other country. One explanation for this result might be that the Polish students in our sample, who study at German universities, are an atypical group. Further studies have to be carried out to further examine this question.

\subsection{The association between academic discipline and religious world-views}

Due to the sampling procedure, the overall sample comprised students from a broad variety of academic disciplines. For the analysis these disciplines were classified into the following eight categories: (1) natural sciences (astronomy, biochemistry, biology, chemistry, geography mathematics, pharmaceutics, physics); (2) technical sciences (chemical engineering, computer sciences, engineering); (3) economic sciences (administration, business, economy); (4) law; (5) languages; (6) health sciences (dentistry, medicine, nursery); (7) human and social sciences (anthropology, communication, education, history, philosophy, political sciences, psychology, sociology); (8) arts (cultural studies, music, theatre, visual and plastic arts). The disciplines were classified in this way, even if at certain universities a particular discipline belongs to a different faculty. (E.g. at the University of Brasilia political science belongs to the law faculty, and not to a faculty of social sciences). Since psychology investigates human behaviour, we have included it into the category of the human and social sciences, even if it is considered as a natural science at most universities.

Table 4: Religiosity and Affinity towards New Age by Area of Science and Sex Results from multiple classification analyses with country, area of science, and sex as dependent variables. Mean values for the countries have been omitted. 


\begin{tabular}{|c|c|c|c|c|c|}
\hline & $n=$ & $\begin{array}{c}\text { RELIGIOUS } \\
\text { BELIEFS } \\
\end{array}$ & $\begin{array}{l}\text { RELIGIOUS } \\
\text { PRACTICE }\end{array}$ & $\begin{array}{l}\text { OCCULT } \\
\text { BELIEFS } \\
\end{array}$ & $\begin{array}{l}\text { NEW AGE- } \\
\text { ACTIVITIES }\end{array}$ \\
\hline GRAND MEAN & 3.408 & 4.83 & 0.90 & 2.51 & 2.27 \\
\hline AREA OF SCIENCE & & \multicolumn{4}{|c|}{ ADJUSTED DEVIATIONS FROM MEAN } \\
\hline Natural Sciences & 453 & .18 & .09 & -.25 & -.47 \\
\hline Technical Sciences & 306 & .15 & -.10 & -.11 & -.37 \\
\hline Economic Sciences & 543 & .43 & .07 & -.19 & -.45 \\
\hline Law & 432 & .15 & .03 & -.02 & -.34 \\
\hline Languages & 244 & .07 & .08 & .37 & .21 \\
\hline Health Sciences & 286 & .38 & -.02 & .18 & .47 \\
\hline Social Sciences & 1.002 & -.59 & -.06 & .05 & .45 \\
\hline Arts & 142 & -.17 & -.17 & .52 & .94 \\
\hline SEX & & \multicolumn{4}{|c|}{ ADJUSTED DEVIATIONS FROM MEAN } \\
\hline Male & 1.502 & -.31 & -.10 & -.34 & -.50 \\
\hline Female & 1.906 & .25 & .08 & .28 & .41 \\
\hline
\end{tabular}

\begin{tabular}{|l|c|c|c|c|c|}
\hline BETA-Values & & & & & \\
\hline COUNTRY & & .46 & .43 & .22 & .20 \\
\hline AREA OF SCIENCE & & .12 & .07 & .08 & .19 \\
\hline SEX & & .09 & .09 & .13 & .19 \\
\hline MULTIPLE R $^{2}$ & & .24 & .20 & .07 & .12 \\
\hline
\end{tabular}

For the analysis we had to take into account that the sex distribution varies greatly across areas of science: $80 \%$ of the students of technical sciences being male, and two thirds of the students of health sciences, social sciences and arts being female. However, the distribution of disciplines varies from country to country, because in most universities the sample included only 4 to 6 classes of students. Since gender and country are important explanatory variables for religious and esoteric beliefs and activities, we have used the statistical procedure of Multiple Classification Analysis, including “country” and "sex" in addition to "area of science” as dependent variables. By means of this multivariate procedure it is possible to calculate the "adjusted mean-values" for the areas of science: i.e. the mean value which each area of science would have if all categories of science had the same distribution of male and female students and the same country-distribution.

Table 4 shows the adjusted mean values of the 4 scales (religious beliefs and practice, occult beliefs, New Age activities) for area of science and for gender, and the beta-coefficients for the three dependent variables. As the cross national differences have been presented already 
in Charts 1 and 2, the mean values for countries are omitted from the table. Of the three dependent variables in the model, country has the highest explanatory power on all four scales, in particular on religious beliefs and religious practice. The effects of sex and area of science are smaller, but nevertheless significant for all four scales.

The rank order of the eight areas of science in regard to occult beliefs and New Age activities corresponds to our expectations: Students of the areas of science which deal primarily with mathematical and logical analysis of physical objects (natural, technical and economic sciences) are more sceptical about occult phenomena and more distanced from New Age activities than are students of those sciences which give more weight to intuition and hermeneutic methods (arts, health sciences, languages, social sciences). In terms of the concept of androgyneity, one could call the first group "male sciences” and the second group of as "female sciences." In fact, the percentage of male students is higher in the exact sciences, whereas the percentage of female students is higher in the areas of arts, health, social and human sciences. In accordance with many other studies (Zulehner 1996, Höllinger 1996 and 1999, Barz), our data confirm that female students are more religious and closer to esotericism than are male students. ${ }^{5}$ In our opinion, the central reason for this difference is that women's behaviour is more often directed by sensitivity and intuition, while men are more likely to act according to rational and logical considerations. Since the access to spiritual experiences and to esoteric and occult phenomena is easier for sensitive and intuitive persons than for rational personalities, women are more open to religion and esotericism.

However, the difference between areas of science in regard to belief in occult phenomena and New Age activities is not merely a consequence of the higher or lower percentage of female students. As can be seen from the adjusted mean values in Table 4, students of languages, health sciences, social sciences and arts have higher scores on occult beliefs and New Age activities also when the sex-distribution is kept constant. This leads us to the assumption that students who choose one of these areas of science should be closer to the pole of "emotional, intuitive and sensitive” personalities, while students of the exact sciences are closer to the pole of "rational" personalities. To investigate this issue, the respondents of the study were asked whether they consider themselves as a "rational” or as an "emotional” personality. The results show in the first part of Table 5 confirm that male students and students of the exact sciences

\footnotetext{
${ }^{5}$ Detailed analysis show that female students are much more likely than their male counterparts to practice esoteric methods (such as astrology, Tarot-cards and fortune-telling), alternative medicine and psychotherapy; also significantly more female than male students interpret their dreams and pay attention at the phases of the moon, when they carry out certain activities. For meditation and for spiritual techniques (Yoga, Zen) we found almost no sex-differences, which might be due to the fact that these methods are less esoteric than the others.
} 
in fact evaluate themselves more frequently as "rational," while female students and students of languages, social sciences and arts consider themselves as more "emotional.” The second part of this table shows the correlations between "rational-emotional" and the scales of religious attitudes, separately for the four culture areas. In fact, the self-evaluation as "emotional" is positively correlated with religious and occult beliefs, and with New Age activities. Between "rational-emotional" and religious practice we found very low correlations for American students, and no correlation at all for European students. We are aware that the self-evaluation as "rational vs. emotional personality" is a very rough measurement for the dimension which we wanted to tap, and that more complex research designs are necessary to confirm our assumptions.

We will now discuss the differences between the eight areas of science in regard to religious beliefs and religious practice. According to Table 4, students of natural sciences, economy, law, health disciplines and languages are more religious than students of arts and of social sciences. This result can be interpreted as a confirmation of the "scholarly distance hypothesis" which has been described in the introduction. Definitely, arts and social sciences are those areas of science which are most concerned with the analysis of social institutions and social values. Thus the lower degree of religiousness among students from these areas of science might be a consequence of their critical analysis of the role of religious institutions in society. 
Table 5: Association between Rational vs. Emotional Personality, Area of Science and Religious Attitudes

a) Self-Evaluation as Rational or Emotional Personality by Area of Science and Sex

Adjusted deviations from mean and beta-values of the multiple classification analysis.

Dependent variables: country, area of science, sex . Means for countries have been omitted. Grand mean for "rational-emotional" = 3.19; Multiple $\mathrm{R}^{2}=0.07$.

\begin{tabular}{|c|c|c|c|c|c|}
\hline AREA OF SCIENCE & $\mathrm{n}=$ & $\begin{array}{l}\text { Adj. devn. } \\
\text { from mean }\end{array}$ & SEX & $\mathrm{n}=$ & $\begin{array}{l}\text { Adj. devn. } \\
\text { from mean }\end{array}$ \\
\hline Natural Sciences & 432 & -.14 & Male & 1.502 & -.27 \\
\hline Economy & 306 & -.10 & Female & 1.906 & .22 \\
\hline Technical Sciences & 453 & -.17 & & & \\
\hline Law & 543 & -.15 & & & \\
\hline Languages & 142 & .21 & & & beta \\
\hline Health Sciences & 244 & -.04 & COUNTRY & & ,14 \\
\hline Social Sciences & 286 & .17 & AREA OF SCIENCE & & ,11 \\
\hline Arts & 1.002 & .27 & SEX & & ,17 \\
\hline
\end{tabular}

b) Correlations between Self-Evaluation as Rational vs. Emotional Personality and Religious Attitudes, by Culture Area (Spearman Rank-Correlations)

\begin{tabular}{|l|r|r|r|r|r|r|r|r|r|}
\hline & & \multicolumn{2}{|c|}{$\begin{array}{c}\text { RELIGIOUS } \\
\text { PRACTICE } \\
\text { (low-high) }\end{array}$} & \multicolumn{2}{c|}{$\begin{array}{c}\text { CHRISTIAN } \\
\text { BELIEFS } \\
\text { (low-high) }\end{array}$} & \multicolumn{2}{|c|}{$\begin{array}{c}\text { NEW AGTIVITIES } \\
\text { AClow-high) }\end{array}$} & \multicolumn{2}{c|}{$\begin{array}{c}\text { OCCULT } \\
\text { BELIEFS } \\
\text { (low-high) }\end{array}$} \\
\hline $\begin{array}{l}\text { RATIONAL VS. } \\
\text { EMOTIONAL }\end{array}$ & $\mathrm{n}=$ & $\mathrm{r}$ & sig. & $\mathrm{r}$ & sig. & $\mathrm{r}$ & sig. & $\mathrm{r}$ & sig. \\
\hline Latin-America & 1952 & .09 & $* *$ & .09 & $* *$ & .07 & $*$ & .12 & $* *$ \\
\hline USA & 275 & .05 & & .16 & $* *$ & .09 & & .09 & \\
\hline South-Europe & 385 & .02 & & .06 & & .10 & & .20 & $* *$ \\
\hline North-West-Europe & 984 & -.01 & & .10 & $* *$ & .22 & $* *$ & .23 & $* *$ \\
\hline
\end{tabular}


Table 6: Association between Political Protest Participation, Area of Science and Religious Attitudes

\section{a) Political Protest Participation by Area of Science and Sex}

Adjusted deviations from mean and beta-values of the multiple classification analysis.

Dependent variables: country, area of science, sex . Means for countries have been omitted. Grand mean for Political Protest Participation $=1.06$; Multiple $\mathrm{R}^{2}=0.10$.

\begin{tabular}{|c|c|c|c|c|c|}
\hline AREA OF SCIENCE & $\mathrm{n}=$ & $\begin{array}{l}\text { Adj. devn. } \\
\text { from mean } \\
\end{array}$ & SEX & $n=$ & $\begin{array}{l}\text { Adj. devn. } \\
\text { from mean }\end{array}$ \\
\hline Natural Sciences & 432 & -.05 & Male & 1.502 & .00 \\
\hline Economy & 306 & -.22 & Female & 1.906 & .00 \\
\hline Technical Sciences & 453 & -.28 & & & \\
\hline Law & 543 & -.17 & & & \\
\hline Languages & 142 & -.05 & & & beta \\
\hline Health Sciences & 244 & .11 & COUNTRY & & ,25 \\
\hline Social Sciences & 286 & .31 & AREA OF SCIENCE & & ,21 \\
\hline Arts & 1.002 & .05 & SEX & & 00 \\
\hline
\end{tabular}

b) Correlation between Political Protest Participation and Religious Attitudes, by Culture Area (Spearman Rank Correlation)

\begin{tabular}{|l|c|r|r|r|r|r|r|r|r|}
\hline & & \multicolumn{2}{|c|}{$\begin{array}{c}\text { RELIGIOUS } \\
\text { PRACTICE } \\
\text { (low-high) }\end{array}$} & $\begin{array}{c}\text { CHRISTIAN } \\
\text { BELIEFS } \\
\text { (low-high) }\end{array}$ & $\begin{array}{c}\text { NEW AGE- } \\
\text { ACTIVITIES } \\
\text { (low-high) }\end{array}$ & \multicolumn{2}{|c|}{$\begin{array}{c}\text { OCCULT } \\
\text { BELIEFS } \\
\text { (low-high) }\end{array}$} \\
\hline $\begin{array}{l}\text { Political Protest } \\
\text { Participation }\end{array}$ & $\mathrm{n}=$ & $\mathrm{R}$ & sig. & $\mathrm{r}$ & sig. & $\mathrm{r}$ & sig. & $\mathrm{r}$ & sig. \\
\hline Latin-America & 1952 & -.03 & & -.09 & $* *$ & .25 & $* *$ & .07 & $* *$ \\
\hline USA & 275 & .16 & $* *$ & .08 & & .17 & $* *$ & .01 & \\
\hline South-Europe & 385 & -.11 & $*$ & -.21 & $* *$ & .26 & $* *$ & .20 & $* *$ \\
\hline North-West-Europe & 984 & -.02 & & -.05 & & .23 & $* *$ & -.01 & \\
\hline
\end{tabular}

The result that students of the social sciences and of arts distance themselves from traditional religion, but have an affinity towards the New Age-movement can be explained also by the “counterculture-hypothesis.” In order to test this hypothesis, respondents were also asked whether they have participated in political protest activities and base-democratic activities such as demonstrations and strikes, solidarity campaigns, local issues committees, or student politics. The resulting scale of "political protest participation” has a mean-value of 1,06: i.e. an average student reports having participated in one of these activities. Table 6 shows that the rate of political protest participation is significantly higher among students of the social sciences, health sciences, and arts than among students of economy, technical sciences and law. The 
second part of Table 6 gives evidence that participation in political protests and participation in New Age activities are in fact correlated. Thus our data confirm that students with countercultural worldviews tend to chose disciplines which are known for their critical attitudes towards society, and at the same time feel closer to New Age activities. The relationship between base-democratic political participation and religiousness is not so clear. In Latin America and in Europe, countercultural political engagement goes hand in hand with a slight tendency to reject traditional religion. In the USA, political engagement and religiousness are positively correlated. This result can be explained by the fact that participation in solidarity campaigns is typical not only for countercultural movements, but also for religious institutions.

We will conclude this chapter with some additional remarks about the differences between the disciplines which were investigated in this study. Of course variations exist among the single disciplines which were summed up into categories. For example, students of the computer sciences are closer to New Age than are students of engineering. Students of chemistry and physics deny the existence of occult phenomena more frequently than do biology students. Students of anthropology, sociology and communication are closer to the New Age movement than are students of philosophy, history and psychology. In most cases, however, the differences between the disciplines of a certain area of science are relatively small when compared to the results for other areas of science. There are two exceptions to this generalization: In the South American countries students of education and students of social work have much higher scores on Christian religiousness, and in contrast, much lower scores on New Age activities than all do other students of social sciences. The reason for this peculiarity seems to be that the students of these disciplines are recruited predominantly from the lower social classes, which are significantly more religious than the middle and upper middle class. In order to avoid diluting the results for our categories, these two groups of South American students have not been included in foregoing the analysis. Another group with surprising results the students of agronomy from the University of Brasilia. Although they belong to a faculty of technical sciences, these students are closer to esotericism than are the students from all other disciplines of that university. This result can be explained by the fact that the Department of Agronomy at the University of Brasilia gives a strong emphasis on environmental and social concerns, thus attracting students with an affinity to ecological and green ideologies. Since these students did not fit into any area of science, and since they were the only class of agronomy students in the combined samples of all universities, they were also excluded from the comparison in Table 4. 


\section{Summary}

In this article we have discussed the results of a cross-national comparative study on religion and esotericism among university students. Even if the lifestyle and the world views of students differ in many regards from those of the rest of the population, students are at the same time influenced by the surrounding socio-cultural environment. Thus in the cross-national comparative perspective, our findings not only are characteristic for students, but in many aspects reflect the religious attitudes of the overall population of the respective countries.

This is true in particular for Christian beliefs and religious practice. In contrast to the classical sociological thesis that modern science would undermine religious beliefs, we found that students, being persons who are trained to think according to the laws of modern science, have more or less the same level of religiousness as the rest of the society they live in. In the USA and in Latin American countries, the percentage of students who believe in the traditional Christian cosmos (God, angels, saints, heaven, hell etc.) is much higher than in Northwestern European countries; South European students are in an intermediate position. Latin American and US American students also are more likely to belief in occult phenomena and esoteric methods (spirits, clairvoyance, psychic healers, astrology etc.) than are Northwestern European students. According to modernisation theories, the persistence of beliefs in religious and magic in Latin America indicates a time lag in the process of secularisation, due to the lower level of socio-economic development of this continent. This argument, however, cannot be applied for the USA. In our opinion, the central factor for explaining the strong affinity towards religion and to a certain degree also towards esoteric beliefs in the USA is the instability and insecurity of life conditions in this country. Geographical and occupational mobility is much higher, kin ties are more dissolved, the nuclear family-system is more unstable, the social security system is less developed, and both property offence and physical violence are more widespread in the USA than in Northwest Europe. Even if students in general do not suffer from the worst forms of material deprivation, they can be affected by many occurrences that make them lose their emotional balance. Many of the mentioned problems are related to the social conditions of immigration societies, and thus the situation in Latin American countries is similar to that of the USA. Thus also the religiousness in Latin America, which rather than losing social importance has become more fervent in recent decades, seems to be motivated to a considerable extent by the instability and insecurity of life conditions on this continent.

From the example of US American culture we can conclude that the disenchantment of the world does not depend on the level of socio-economic and technical modernisation only; it also 
depends on whether or not individuals experience emotional and social stability in their everyday life. As Mongardini $(1987,17)$ and others have argued, in situations of a dissolution of social formations a return to religion and to magic can take place. The "refuge to religion" or to esoteric methods in order to make existential problems more easily supportable has been criticised by social scientists as an immature state of human mind and behaviour, as an escape from reality into the realm of fantasy etc. We do not deny that this is an important point of view when talking scientifically about religion and esotericism. However religion and magic do have also other aspects and functions. The fervent religiosity in both parts of America reminds us that religion in its more traditional forms and also in its modern forms can be a strong source of energy and vitality.

In this study, the dissemination of New Age activities was also investigated. Accordingly, we considered spiritual techniques (Yoga, meditation), alternative methods of healing (homeopathy, acupuncture), esoteric methods of prediction of events and of psychoanalysis (Tarot-cards, astrology), and also some methods of humanist psychology (psychotherapy, dream interpretation). Our investigation shows that most students have at least a few experiences with such practices. A considerable number of students has a somewhat closer contact to the esoteric market: Between $20 \%$ and $30 \%$ in the single countries have practiced at least five (of the list of twelve) different techniques. However, only a relatively small proportion practices one or more methods regularly. This result confirms a typical aspect of New-Age religiosity: the tendency to experiment with various techniques at the same time or with one after another rather than to immerge more profoundly into one specific method.

The pattern of dissemination of New Age activities across culture areas is not as distinct as in the case of religiosity and occult beliefs. Asian methods of spirituality and healing (like Yoga, acupuncture, Tarot and I-Ging) are practiced more frequently by students from Northwestern European countries. Outside Europe these methods have a higher degree of dissemination in metropolitan centers (such as Brasilia, Montevideo and Medellin) than in smaller and more provincial cities. Esoteric methods, which have a long tradition in Western society (psychic-healing or faith-healing, fortune-telling) are practiced more frequently by Latin American and US American students. For some items, such as alternative medicine, dream interpretation and observation of the moon phases, we did not find any meaningful crossnational pattern. When looking at the cross-national results for New Age activities together with the results for religiousness and esoteric beliefs, we can say that the esoteric practice of Northwest European students come close to Wouter Haanegraafs description of the New Age movement as "secularised esoterism": i.e. esoteric and spiritual methods used for holistic (i.e. 
cognitive, sensual and emotional) experiences and for exploring one's own personality, without their traditional religious or spiritual connotations (see also: Barz 1992, 93; Hervieu-Léger 1993). In contrast, in Latin America and also in the USA esoteric and spiritual methods are seen more in their traditional form as linked to a sacred cosmos of divine and spiritual entities.

In the second part of this article we analysed gender differences and differences between areas of science in relation to attitudes towards religion and esotericism. Consistent with many previous studies on this issue, we found that female students are more religious and much closer to esotericism than are male students. Independent of their sex, students of the exact sciences (natural, technical and economic sciences) and law students are more sceptical about occult phenomena and have significantly less experience with New Age activities than do students of languages, health sciences, social sciences and arts. Our explanation for these differences is that students with a predominance of "male" personality traits (according to the theory of the androgynous personality) tend to chose disciplines such as the exact sciences and law, which emphasize on formal thinking, calculating and planning, and which facilitate upward mobility in modern society: i.e. the areas of economy and public administration. Their cognitive approach towards the world and their conviction that humanity in our times is able to control ever more phenomena of nature and to solve ever more economic and social problems by means of calculation and planning is incompatible with belief in occult phenomena, spirits etc., which cannot be proved with the instruments of modern science. Their realistic views about political and economic constraints and their aspiration to advance into influential positions within the established social system bring them in sceptical distance from the utopian ideas of the New Age movement. In contrast, persons with a stronger disposition for the "female" qualities of sensitivity and intuition feel more attracted to disciplines which investigate the human personality in a more holistic way, including also the emotional, irrational and spiritual aspects of life. Because of their sensitivity they are more vulnerable and more strongly affected by interpersonal tensions and social problems. Thus they are more open to and more in need of therapeutic, esoteric and spiritual methods of life support. At the same time they feel attracted to countercultural movements, including the New Age movement which gives voice to their own discontent about modern society.

Among students of the social sciences and of arts, these countercultural tendencies are particularly strong and manifest themselves also in a strong tendency to reject the established religious institutions and their beliefs and ideologies, which these statements consider as conservative, sclerotic and hypocritical. For their part, students from the other areas of science, 
who are more willing to integrate themselves into the established social system, are also more likely to follow the traditional norms of religious behaviour in their society. 


\section{Literature}

Barker Eileen (1993): Neue religiöse Bewegungen, in: Kölner Zeitschrift für Soziologie und Sozialpsychologie, SH 33, 231-248.

Barz Heiner: Religion ohne Institution. Jugend und Religion 1, Opladen 1992

Beit-Hallahmi Benjamin/Michael Argyle (1998): The Psychology of Religious Behaviour. Belief and Experience, London-New York.

Bellah Robert N. (1976): The New Religious Consciousness and the Crisis of Modernity, in: Charles Y. Glock/Robert N. Bellah (ed).: The New Religious Consciousness, University of California Press, 13352.

Berger Peter/Brigitte Berger/Hans-Peter Dreitzel (1973): The Homeless Mind, New York

Bergbom Barbara/Kaj Bjprkqvist, Nils G. Holm (1996): A cross-cultural investigation of world view: Student samples from ten countries, in: Holm Nils G./Kai Björkqvist (ed): World Views in Modern Society. Empirical Studies on the Relationship between World View, Culture, Personality and Upbringing, Abo Akademi University, Finland, 29-46.

Bierhoff-Alfermann Dorothee (1989): Androgynie. Möglichkeiten und Grenzen der Geschlechterrollen, Opladen.

Bochinger Christoph (1994): “New Age” und moderne Religion. Religionswissenschaftliche Analysen, Gütersloh.

Corten André (1996): Os pobres eo espírito santo. O pentecostalismo no Brasil, Petrópolis.

Durkheim, Emile (1965): The Elementary Forms of Religious Life, New York

Ferreira de Camargo Cándido Procopio (1973): Católicos, Protestantes, Espíritas, Petropolis.

Hanegraaff Wouter J.(1996): New Age Religion and Western Culture. Esotericism in the Mirror of Secular Thought, Leiden-New York-Köln.

Heelas Paul (1996): The New Age Movement. The Celebration of the Self and the Sacralization of Modernity, Oxford.

Hervieu-Léger Danièle (1993): Present-Day Emotional Renewals. The end of Secularisation or the End of Religion? in: William H. Swatos Jr. (ed.): A future for Religion? Newbury Park-London-Delhi, 129148.

Höllinger, Franz (1996): Volksreligion und Herrschaftskirche. Die Wurzeln religiösen Verhaltens in westlichen Gesellschaften, Opladen.

Höllinger Franz (1999): Astrologie, Yoga und Politik. New Age und politische Orientierungen bei StudentInnen, in: Soziale Welt 50/1 (in print).

Holm Nils G./Kai Björkqvist (1996): World Views in Modern Society. Empirical Studies on the Relationship between World View, Culture, Personality and Upbringing, Abo Akademi University, Finland.

Jagodzinski Wolfgang/Karel Dobbelaere (1993): Der Wandel kirchlicher Religiosität in Westeuropa, in: Kölner Zeitschrift für Soziologie und Sozialpsychologie, SH 33, 1993, 68-91.

Kaufmann Franz-Xaver (1989): Religion und Modernität. Tübingen

Keller Heidi (1978): Männlichkeit - Weiblichkeit, Darmstadt.

Knoblauch Hubert (1991): Die Verflüchtigung der Religion ins Religiöse, in: Thomas Luckmann: Die unsichtbare Religion, Frankfurt/M., 7-41.

Knoblauch Hubert (1989): Das unsichtbare neue Zeitalter: "New Age”, privatisierte Religion und kultisches Milieu, in: Kölner Zeitschrift für Soziologie und Sozialpsychologie 41, 504-525.

Larson Edward J./Larry Witham (1997): Scientists are Still Keeping the Faith, Nature 386, 435-36 
Lehmann E.C./D.W. Schriver (1968): Academic discipline as predictive of faculty religiosity, Social Forces 47, 171-182.

Lübbe Hermann (1986): Religion nach der Aufklärung, Graz-Wien-Köln.

Martin David (1978): A General Theory of Secularisation, Oxford.

Martin David (1990): Tongues of Fire. The Explosion of Protestantism in Latin America, Oxford.

Marty E. Marty/R. Scott Appleby (1996): Herausforderung Fundamentalismus. Radikale Christen, Moslems und Juden im Kampf gegen die Moderne, Frankfurt - New York.

Mol Hans (ed.) (1972): Western religion. A country by country analysis, Den Haag-Paris.

Mongardini Carlo (1987): Über die soziologische Bedeutung des magischen Denkens; in: Arnold Zingerle/Carlo Mongardini (Ed.): Magie und Moderne, Berlin 1987, 11-62

Moreira Alves Márcio (1979): A igreja e a política no Brasil, Editora Brasiliense 1979

Mörth Ingo (1989): New Age - neue Religion? Theoretische Überlegungen und empirische Hinweise zur sozialen Bedeutung des Wendezeit-Syndroms, in: M. Haller/H.G. Hoffmann-Novottny/W. Zapf (eds.): Kultur und Gesellschaft, Frankfurt-New York, 297-320.

Müller Lutz (1989): Magie. Tiefenpsychologischer Zugang zu den Geheimwissenschaften, Stuttgart.

Niebuhr, Richard (1929): The social sources of denominationalism, Cleveland.

Parker Christián G.(1998): Modern Popular Religion: A Complex Object of Study for Religion, in: International Sociology, Vol. 13/2, 195-212.

Pierucci A. Flávio/Reginaldo Prandi (1996): A realidade social das religiões no Brasil, São Paulo.

Rios, José Arthur (1994): Sentimento Religioso no Brasil , in: L.P. Horta (ed.): Sagrado e Profano: XI retratos de um Brasil fim de século, Rio de Janeiro, 21-45

Siqueira Deis (1999): Práticas místicas e esotéricas na capital do Brasil. A construção do sujeito - objeto de investigação, Série Sociológica, Universidade de Brasilia, Brasilia.

Stark Rodney/William S. Bainbridge (1985): The Future of Religion. Secularisation, Revival and Cult Formation, Berkley-Los Angeles-London.

Stenger Horst (1993): Die soziale Konstruktion okkulter Wirklichkeit. Eine Soziologie des "New Age”, Opladen.

Waßner Rainer (1984): Magie und Psychotherapie, Berlin

Weber Max (1988): Gesammelte Aufsätze zur Wissenschaftslehre, Tübingen (First: 1922).

Zulehner Paul/Hermann Denz (1993): Wie Europa lebt und glaubt, Düsseldorf . 